\title{
Diseases presenting with vesicular and erosive lesions of oral mucous membranes
}

\section{Choroby przebiegające ze zmianami pęcherzowymi i nadżerkowymi błony śluzowej jamy ustnej}

\author{
Kamila Ociepa, Agnieszka Żebrowska \\ Department of Dermatology and Venereology, Medical University of Lodz, Poland \\ Klinika Dermatologii i Wenerologii Uniwersytetu Medycznego w Łodzi, Polska
}

Dermatol Rev/Przegl Dermatol 2017, 104, 509-518

DOI: https://doi.org/l0.51/4/dr.2017.71216

\author{
CORRESPONDING AUTHOR/ \\ ADRES DO KORESPONDENCJI: \\ lek. Kamila Ociepa \\ Klinika Dermatologii \\ i Wenerologii \\ Uniwersytet Medyczny \\ Plac Hallera 1 bud. 6 \\ 90-647 Łódź, Polska \\ tel.: +48 426862570 \\ e-mail: kaociepa@gmail.com
}

\begin{abstract}
Disorders of the oral mucosa are an area of interdisciplinary cooperation involving physicians from a diverse range of medical specialties. Diseases characterized by a similar mucosal abnormalities include lichen planus, pemphigus vulgaris, paraneoplastic pemphigus, mucous membrane pemphigoid, epidermolysis bullosa acquisita, linear IgA bullous dermatosis and chronic ulcerative stomatitis.
\end{abstract}

\section{STRESZCZENIE}

Choroby błony śluzowej jamy ustnej stanowią obszar interdyscyplinarnej współpracy lekarzy wielu specjalności. Do jednostek chorobowych o podobnym obrazie klinicznym zmian występujących na błonach śluzowych należą: liszaj płaski jamy ustnej, pęcherzyca zwykła, pęcherzyca paraneoplastyczna, pemfigoid błon śluzowych, nabyte pęcherzowe oddzielanie się naskórka, linijna IgA dermatoza pęcherzowa oraz przewlekłe wrzodziejące zapalenie jamy ustnej.

Key words: lichen planus, pemphigus vulgaris, paraneoplastic pemphigus, mucous membrane pemphigoid, epidermolysis bullosa acquisita, chronic ulcerative stomatitis.

Słowa kluczowe: liszaj płaski, pęcherzyca zwykła, pęcherzyca paraneoplastyczna, pemfigoid błon śluzowych, nabyte pęcherzowe oddzielanie się naskórka, przewlekłe wrzodziejące zapalenie jamy ustnej.

\section{INTRODUCTION}

The differential diagnostics of oral mucosa diseases poses a considerable challenge in clinical practice, which is due both to the wide spectrum of

\section{WPROWADZENIE}

Diagnostyka różnicowa chorób błony śluzowej jamy ustnej stanowi znaczący problem w praktyce klinicznej, wynikający zarówno z szerokiego spektrum 
pathological conditions of diverse aetiology and the absence of features specific to different nosological entities. The study discusses the clinical characteristics of oral mucosal lesions accompanying a range of diseases including lichen planus, pemphigus vulgaris, paraneoplastic pemphigus, mucous membrane pemphigoid, epidermolysis bullosa acquisita, linear IgA bullous dermatosis and chronic ulcerative stomatitis.

\section{LICHEN PLANUS (LP)}

Lichen planus of the oral cavity is a highly prevalent chronic disease affecting between $0.1 \%$ and $2.2 \%$ of the general population. It occurs most commonly in the fifth and sixth decades of life, however is may develop practically at any age. The condition affects women twice as often as men $[1,2]$.

Despite extensive studies the aetiology of LP remains unclear. The condition involves cellular immune response with T cell activity and predominance of the CD8 subpopulation of helper cells [2]. The familial occurrence of the disease suggests a certain genetic predisposition. Multiple literature reports indicate that LP frequently coexists with hepatitis B and C. Also, a number of sources mention stress as a causative factor for the disease. Local factors contributing to the development of lesions have been reported to include chemical, toxic and mechanical trauma. Among chemical factors, attention is given both to medications and chemical compounds present in dental materials (e.g. amalgam), colourants, preservatives and fragrances, herbs, propolis, fluorine contained in toothpaste, dental floss and mouthwash formulations, as well as soft drinks and food products [3, 4]. Medications with a potential to contribute to the development of LP include arsenic, mercury, gold and lithium compounds, angiotensin-converting-enzyme inhibitors, $\beta$-blockers, ibuprofen and furosemide [1, 2].

In 1978 the World Health Organization (WHO) distinguished 6 forms of oral LP: reticular, bullous, papular, plaque-like, atrophic and erosive [5]. However, in clinical practice physicians make use of a simplified classification proposed by Eisen et al., which consists of just two subtypes: reticular (R), presenting only as white papules or lines having a network arrangement, and more severe atropho-erosivus (AE), accompanied by tissue thinning, erosions and bullae [6].

The most common clinical form is the reticular subtype developing at the line of contact between the teeth and buccal mucosa and manifesting as symmetrical white streaks appearing in tree-like configurations (Wickham's striae). Lichen planus located on the tongue usually takes the plaque-like stanów patologicznych o zróżnicowanej etiologii, jak i braku charakterystycznych cech klinicznych poszczególnych jednostek chorobowych. W pracy omówiono obraz kliniczny zmian w obrębie błony śluzowej jamy ustnej w przebiegu liszaja płaskiego, pęcherzycy zwykłej, pęcherzycy paraneoplastycznej, pemfigoidu błon śluzowych, nabytego pęcherzowego oddzielania się naskórka, linijnej IgA dermatozy pęcherzowej oraz przewlekłego wrzodziejącego zapalenia jamy ustnej.

\section{LISZAJ PŁASKI (LICHEN PLANUS - LP)}

Liszaj płaski jamy ustnej jest powszechną, przewlekłą chorobą, która występuje u 0,1-2,2\% ogółu populacji. Najczęściej pojawia się w 5. i 6 . dekadzie życia, jednak można ją stwierdzić w każdym wie$\mathrm{ku}$. Schorzenie to dotyczy ponad 2-krotnie częściej kobiet niż mężczyzn [1,2].

Etiologia LP, pomimo licznych badań, nadal jest nieznana. Obserwuje się reakcję immunologiczną typu komórkowego z aktywnością limfocytów T i przewagą limfocytów pomocniczych subpopulacji CD8 [2]. Rodzinne występowanie choroby sugeruje pewną predyspozycję genetyczną. W piśmiennictwie stwierdzono częste współwystępowanie LP z wirusowym zakażeniem wątroby typu B i C. W wielu źródłach jako czynnik sprawczy podawany jest stres. Wśród czynników miejscowych przyczyniających się do rozwoju zmian wymienia się: urazy chemiczne, toksyczne i mechaniczne. Spośród czynników chemicznych bierze się pod uwagę leki, a także związki chemiczne występujące w materiałach stomatologicznych (np. amalgamat), związki koloryzujące, konserwujące, zapachowe, zioła, propolis, fluor - obecne w pastach do zębów, niciach dentystycznych, płynach do płukania jamy ustnej, napojach kolorowych oraz produktach pokarmowych $[3,4]$. Do leków mogących przyczynić się do wystąpienia LP zalicza się: związki arsenu, rtęci, złota, litu, inhibitory konwertazy angiotensyny, $\beta$-adrenolityki, ibuprofen oraz furosemid $[1,2]$.

W 1978 r. Światowa Organizacja Zdrowia (WHO) wyróżniła 6 postaci LP błony śluzowej jamy ustnej: siateczkową, pęcherzykową, nadżerkową, plamkową, zanikową i wrzodziejącą [5]. W praktyce klinicznej dla ułatwienia posługujemy się jednak uproszczoną klasyfikacją, którą zaproponowali Eisen i wsp. Wyróżnia ona dwie postacie: siateczkową (reticular - R), ze zmianami wyłącznie barwy białej występującymi jako grudki lub siateczka, oraz bardziej zaawansowaną zanikowo-nadżerkową (atropho-erosivus - AE), ze ścieńczeniami, nadżerkami i pęcherzami [6].

Najczęstszą odmianą kliniczną jest postać siateczkowa - symetryczne, białe, drzewkowate linie wzdłuż kontaktu zębów z błoną śluzową policzków (prążki Wickhama). W przypadku lokalizacji zmian na języku LP ma zwykle postać płytkową. Postać zanikowa może 


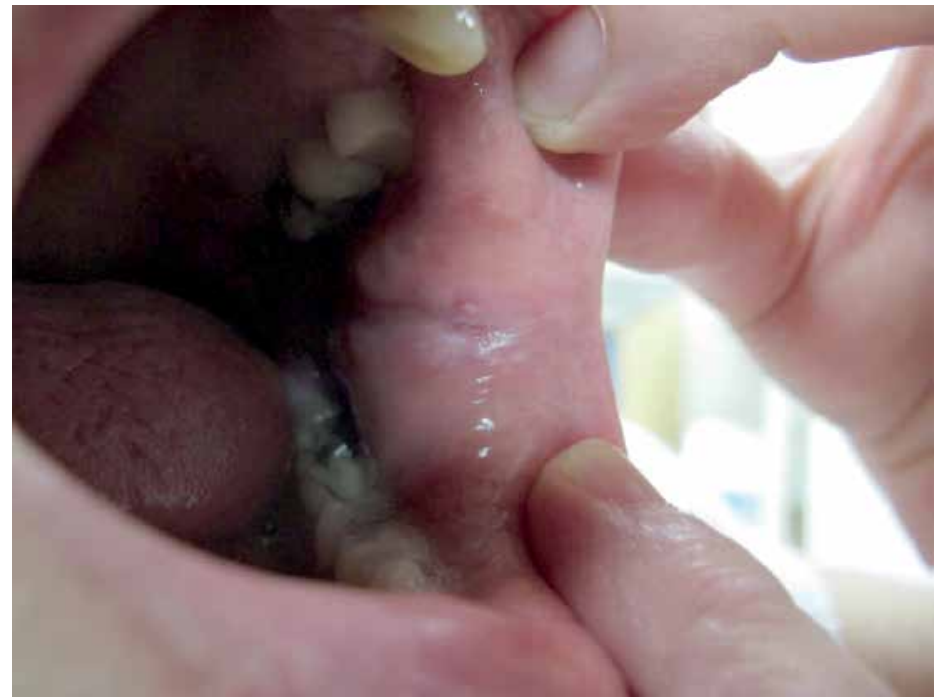

Figure I. Lichen planus of oral mucosa

Rycina I. Liszaj płaski błony śluzowej jamy ustnej

form. The atrophic subtype can either occur alone or accompany the erosive form of oral lichen planus [7, 8] (Fig. 1).

Lichen planus typically runs a course of many years. Although the risk of squamous cell carcinoma secondary to LP is low, such cases have been described in the literature. The greatest risk exists in patients with atrophic and erosive oral LP on account of the prolonged inflammatory process $[9,10]$

Oral lichen planus can be asymptomatic, but it can also present with very severe pain which significantly impairs the quality of life of patients. Unlike the reticular form, which is not usually very painful, bullous/erosive lesions are associated with severe pain.

\section{LICHEN PLANUS PEMPHIGOIDES (LPP)}

Lichen planus pemphigoides is a rare disease of unclear aetiology. It affects men more commonly than women, and the peak age of onset is at 30-40 years [11]. Pathological lesions in bullous lichen planus are caused by lymphoid infiltration within the dermoepidermal junction, whereas LPP is an autoimmune disease. Clinical manifestations of LPP in the initial phase of the disease are typical of LP. After several weeks or months, however, bullous or vesicular lesions develop in locations other than papular lesions characteristic of LP. The development of bullae on unchanged skin distinguishes LPP from the bullous form of LP. The difference between LPP and bullous pemphigoid is the presence of papules. From several to about a dozen percent of patients develop erosions over erythematous lesions within the oral mucosa, along with LP-characteristic white patches, or desquamative gingivitis [12-15]. występować zarówno samodzielnie, jak i z postacią nadżerkową $[7,8]$ (ryc. 1).

Przebieg LP jest zazwyczaj wieloletni. Ryzyko rozwoju raka płaskonabłonkowego w przebiegu LP jest niskie, ale takie przypadki były w literaturze opisywane. Najbardziej narażeni są pacjenci z odmianą zanikową i nadżerkową LP jamy ustnej ze względu na długotrwały proces zapalny $[9,10]$.

Liszaj płaski jamy ustnej może przebiegać bezobjawowo albo powodować silne dolegliwości bólowe upośledzające znacznie jakość życia pacjentów. W postaci siateczkowej na ogół nie występują silne dolegliwości bólowe, natomiast zmiany pęcherzykowo-nadżerkowe powodują silny ból.

\section{LISZAJ PŁASKI PEMFIGOIDOWY (LICHEN PLANUS PEMPHIGOIDES - LPP)}

Liszaj płaski pemfigoidowy jest rzadką chorobą o nieznanej etiologii. Występuje częściej u mężczyzn oraz $\mathrm{z}$ reguły przypada na 3.-4. dekadę życia [11]. Zmiany chorobowe w liszaju płaskim pęcherzowym są spowodowane limfoidalnym naciekiem w obrębie połączenia skórno-naskórkowego, natomiast LPP jest chorobą autoimmunologiczną. Objawy kliniczne LPP w pierwszej fazie choroby są typowe dla LP. Po kilku tygodniach lub miesiącach pojawiają się zmiany pęcherzowe lub pęcherzykowe w miejscach niezależnych od zmian grudkowych charakterystycznych dla LP. Wystąpienie zmian pęcherzowych na niezmienionej skórze odróżnia LPP od pęcherzowej odmiany LP, a obecność grudek od pemfigoidu pęcherzowego. U kilku do kilkunastu procent chorych na błonach śluzowych jamy ustnej pojawiają się nadżerki na podłożu zmian rumieniowych oraz zmleczeń typowych dla LP lub złuszczające zapalenie dziąseł [12-15]. 


\section{PEMPHIGUS VULGARIS (PV)}

Pemphigus vulgaris is a rare chronic autoimmune disease with an incidence of 1-5 cases/1 million population/year. The disease affects patients between 30 and 60 years of age, with no significant predilection for sex $[16,17]$. A key role in the aetiopathogenesis of the condition is attributed to IgG class antibodies directed against desmosomal cadherins - desmoglein-3 (DSG3) and desmoglein-1 (DSG1). They are cadherins which determine mutual adhesion of keratinocytes $[16,17]$. An important part in the development of the disease is also played by external factors. The list of exogenous and endogenous factors potentially contributing to the emergence of the disease in genetically predisposed individuals is long. It comprises physical factors, burns, X-radiation, UV radiation, hormones, mechanical trauma, stress and pharmaceutical drugs [18].

It is estimated that in over $50 \%$ of cases symptoms initially involve only the oral mucosa. Mucosal lesions present as very painful erosions with poorly defined margins, located in the area of the cheeks, tongue, soft palate and lower lip. Typical bullae in the oral cavity are rarely seen, which considerably complicates the diagnostic process [19, 20] (Figs. 2, 3). Fifty percent of patients with PV report upper respiratory tract symptoms and laryngological examination reveals typical bullous lesions in $80 \%$ of them. For this reason, patients often experience sore throat, hoarse voice or dysphagia.

The majority of patients with the mucosal variant of PV develop typical cutaneous lesions over a period of a few months. However, it is not uncommon for the disease to present only with lesions involving the mucous membranes.

\section{PECCHERZYCA ZWYKŁA (PEMPHIGUS VULGARIS - PV)}

Pęcherzyca zwykła jest przewlekłą, rzadką chorobą autoimmunologiczną. Częstość występowania szacuje się na 1-5 przypadków na milion osób rocznie. Choroba dotyczy pacjentów między 30. a 60. rokiem życia, bez istotnej predylekcji do płci $[16,17]$. W etiopatogenezie ważną rolę odgrywają autoprzeciwciała w klasie IgG skierowane przeciwko desmosomalnym kadherynom - desmogleinie 3 (DSG3) i desmogleinie 1 (DSG1). Są to kadheryny, które warunkują wzajemne przyleganie keratynocytów $[16,17]$. Istotną funkcję w rozwoju choroby pełnią również czynniki zewnętrzne. Lista czynników egzogennych i endogennych, które mogą wywołać chorobę u osób predysponowanych genetycznie, jest długa. Należą do nich: czynniki fizykalne, oparzenia, promieniowanie rentgenowskie, promieniowanie UV, hormony, urazy mechaniczne, stres i leki [18].

Szacuje się, że w ponad 50\% przypadków objawy początkowo występują jedynie w obrębie błony śluzowej jamy ustnej. Zmiany na śluzówkach mają postać nieostro odgraniczonych, bardzo bolesnych nadżerek występujących na policzkach, języku, podniebieniu miękkim, a także w obrębie dolnej wargi. Typowe pęcherze w jamie ustnej obserwuje się rzadko, co istotnie utrudnia diagnostykę [19, 20] (ryc. 2, 3). Spośród pacjentów z PV 50\% zgłasza dolegliwości w obrębie górnych dróg oddechowych, a u 80\% z nich w badaniu laryngologicznym stwierdza się charakterystyczne zmiany pęcherzowe. $Z$ tego powodu pacjenci często skarżą się na ból gardła, chrypkę i dysfagię.

U większości pacjentów z postacią śluzówkową PV w czasie kilku miesięcy rozwijają się typowe zmiany skórne. Może się jednak zdarzyć, że choroba będzie przebiegała jedynie ze zmianami w obrębie błon śluzowych.

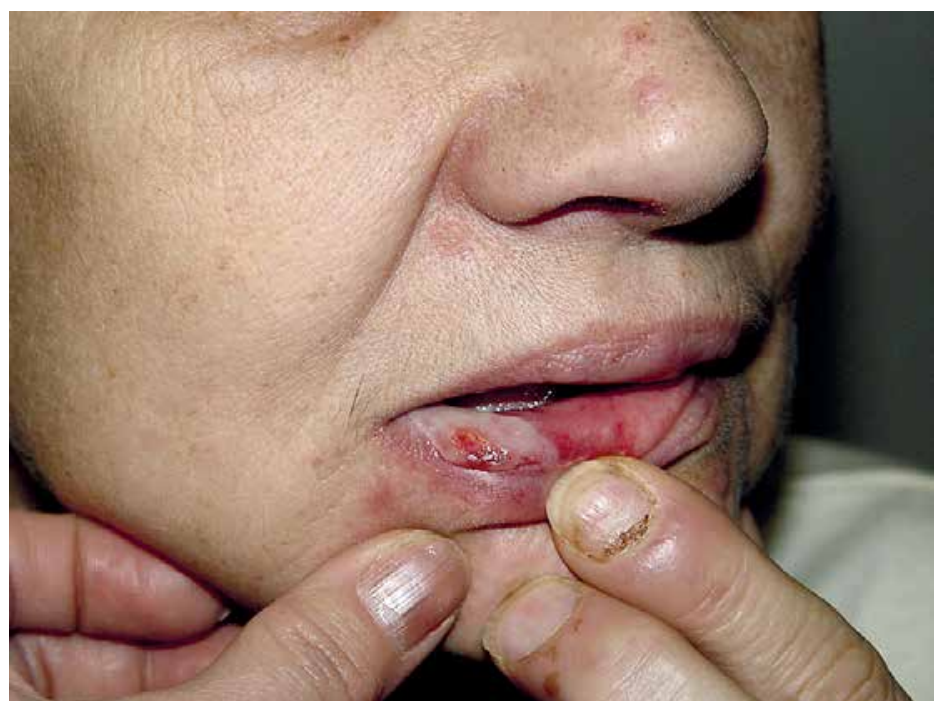

Figure 2. Pemphigus vulgaris

Rycina 2. Pęcherzyca zwykła 

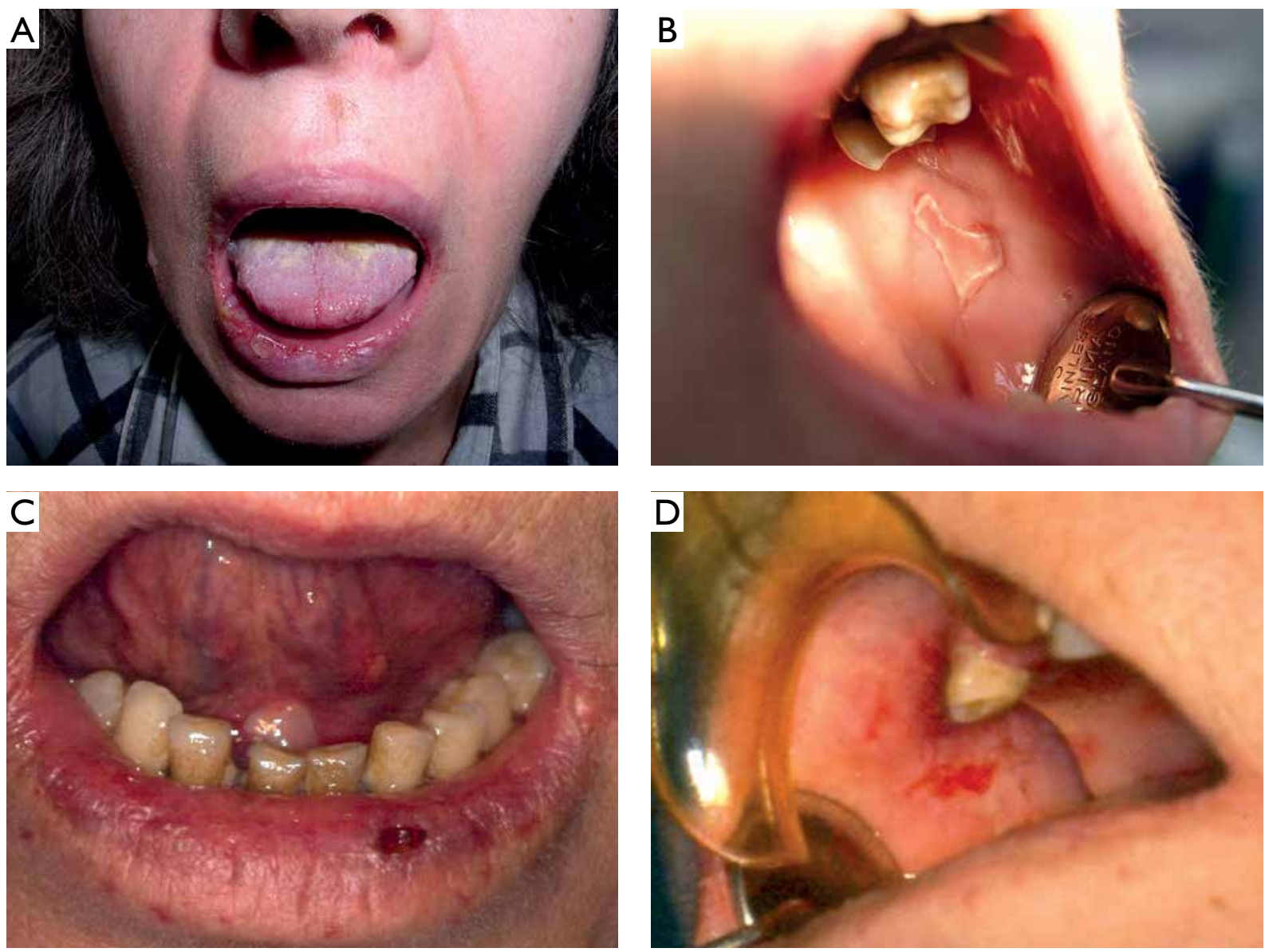

Figure 3. Pemphigus vulgaris

Rycina 3. Pęcherzyca zwykła

It is crucial to note that the correct diagnosis is established during 6 months in nearly $100 \%$ of cases involving cutaneous lesions and in approximately $57 \%$ of cases with isolated mucosal lesions. Retrospective studies show that in over $70 \%$ of patients with the mucosal variant of PV the diagnosis was usually made by physicians of several medical specialties $[21,22]$.

\section{PEMPHIGUS PARANEOPLASTICUS (PNP)}

Pemphigus paraneoplasticus is a rare type of pemphigus which is always related to cancer. The most common cancer types accompanying PNP include B-cell lymphoma, chronic lymphocytic leukaemia, Castleman's disease, Waldenström's macroglobulinaemia and thymoma [23, 24].

The clinical picture of PNP is varied and may resemble conditions ranging from LP or erythema multiforme to PV. Oral mucosa often reveals painful haemorrhagic erosions extending as far as the oral part of the pharynx. Characteristic for the disease are also thick-layered scabs located on the lips (Fig. 4). The nails are frequently affected by abnormalities

Na uwagę zasługuje fakt, że prawidłowe rozpoznanie w przypadku zmian skórnych ustala się w czasie 6 miesięcy u niemal 100\% pacjentów, natomiast w izolowanych zmianach śluzówkowych u ok. 57\%. Badania retrospektywne wykazują, że ponad $70 \%$ pacjentów ze śluzówkową postacią PV było diagnozowanych przez lekarzy kilku specjalności [21, 22].

\section{PECCHERZYCA PARANEOPLASTYCZNA (PEMPHIGUS PARANEOPLASTICUS - PNP)}

Pęcherzyca paraneoplastyczna jest rzadkim typem pęcherzycy, której zawsze towarzyszy choroba nowotworowa. Najczęściej rozpoznaje się: chłoniak B-komórkowy, przewlekłą białaczkę limfocytową, chorobę Castelmana, makroglobulinemię Waldenströma oraz grasiczak [23, 24].

Obraz kliniczny PNP jest różny, mogą występować zmiany podobne do LP, rumienia wielopostaciowego lub PV. Na śluzówkach jamy ustnej często stwierdza się krwotoczne, bolesne nadżerki sięgające aż do ustnej części gardła. Na wargach występują typowe dla tego schorzenia, grubo uwarstwione strupy (ryc. 4). Często są obecne zmiany na paznokciach - od znie- 


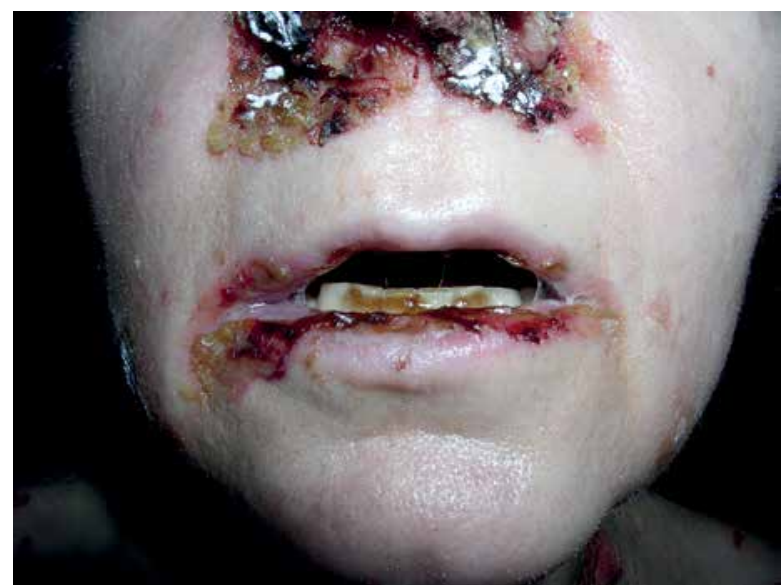

Figure 4. Pemphigus paraneoplasticus

Rycina 4. Pęcherzyca paraneoplastyczna

ranging from deformities to complete nail plate loss and pterygium formation.

\section{MUCOUS MEMBRANE PEMPHIGOID (MMP)}

Mucous membrane pemphigoid is a disease of autoimmune origin. The aetiopathogenesis of MMP has not been fully elucidated, though it is likely to have an immunological basis together with genetic predisposition. The incidence is $0.5-3.2$ cases/100,000 population/year. Mucous membrane pemphigoid affects predominantly individuals over the age of 60 , and women are twice as likely to be affected as men [25].

The clinical features are not very distinctive. Subepidermal bullae may be seen on the mucous membranes in the nasopharyngeal cavity, oral cavity, eyes, larynx, oesophagus, genital organs and also on the skin $[26,27]$. The most common locations include the oral mucosa, which is affected in $90.2 \%$ of cases, and the conjunctiva, involved in $60.1-80 \%$ of cases [28, 29]. A common and the most characteristic manifestation of pemphigoid is desquamative gingivitis (Fig. 5). Typical bullae on the oral mucosa are rarely observed, though more frequently than in cases of PV. The clinical picture of MMP is much more typically dominated by painful irregularly shaped erosions. The entire oral cavity may be affected. Concurrent cutaneous lesions involving primarily upper trunk sections can be seen in one-third of all patients. Typical scarring usually does not develop when the disease is limited to the oral mucosa [30].

\section{EPIDERMOLYSIS BULLOSA ACQUISITA (EBA)}

Epidermolysis bullosa aquisita is a rare autoimmune disease which usually affects patients between 40 and 60 years of age without any sex predilection.

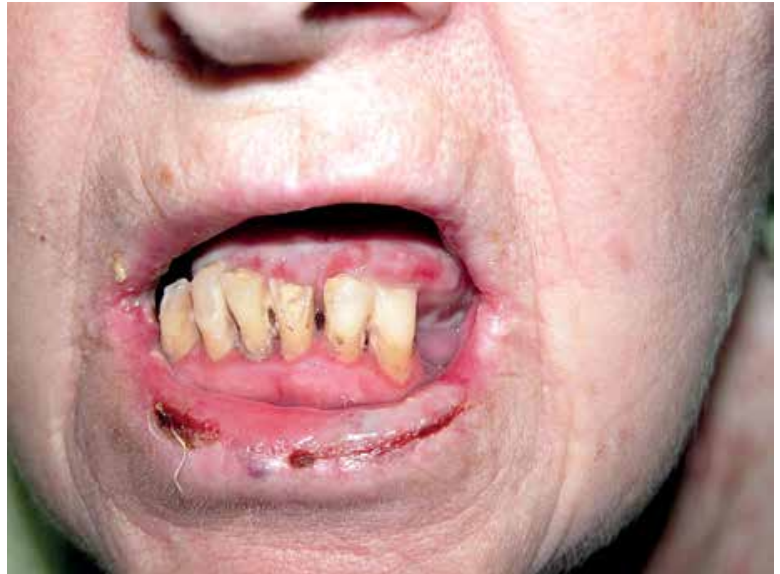

kształceń do całkowitej utraty płytki z wytworzeniem skrzydlika.

\section{PEMFIGOID BŁON ŚLUZOWYCH (MUCOUS MEMBRANE PEMPHIGOID - MMP)}

Jest to choroba o podłożu autoimmunologicznym. Etiopatogeneza MMP nie została do końca poznana, najbardziej prawdopodobne jest tło immunologiczne oraz predyspozycje genetyczne. Częstość występowania wynosi 0,5-3,2 przypadku na 100 tysięcy osób rocznie. Najczęściej stwierdza się ją u osób po 60. roku życia, dwukrotnie częściej u kobiet [25].

Obraz kliniczny jest mało charakterystyczny. Podnaskórkowe pęcherze mogą być obecne na błonach śluzowych jamy nosowo-gardłowej, jamy ustnej, oczu, krtani, przełyku, narządów płciowych, a także na skórze [26, 27]. Najczęstszymi lokalizacjami są błona śluzowa jamy ustnej - w 90,2\% przypadków, oraz spojówki - w 60,1-80\% przypadków [28, 29]. Częstym i najbardziej charakterystycznym objawem dla pemfigoidu jest złuszczające zapalenie dziąseł (ryc. 5). Rzadko, choć z większą częstością niż w przypadku PV, obserwuje się typowe pęcherze na śluzówkach jamy ustnej. Zwykle w obrazie klinicznym dominują nieregularne, bolesne nadżerki. Zmiany mogą występować w całej jamie ustnej. U 1/3 pacjentów można jednocześnie stwierdzić zmiany skórne zajmujące głównie górne części tułowia. Charakterytyczne bliznowacenie $\mathrm{z}$ reguły nie występuje w przypadku choroby ograniczonej do błony śluzowej jamy ustnej [30].

\section{NABYTE PĘCHERZOWE ODDZIELANIE SIĘ NASKÓRKA (EPIDERMOLYSIS BULLOSA ACQUISITA - EBA)}

Nabyte pęcherzowe oddzielanie się naskórka jest rzadką chorobą autoimmunologiczną, niewykazującą 


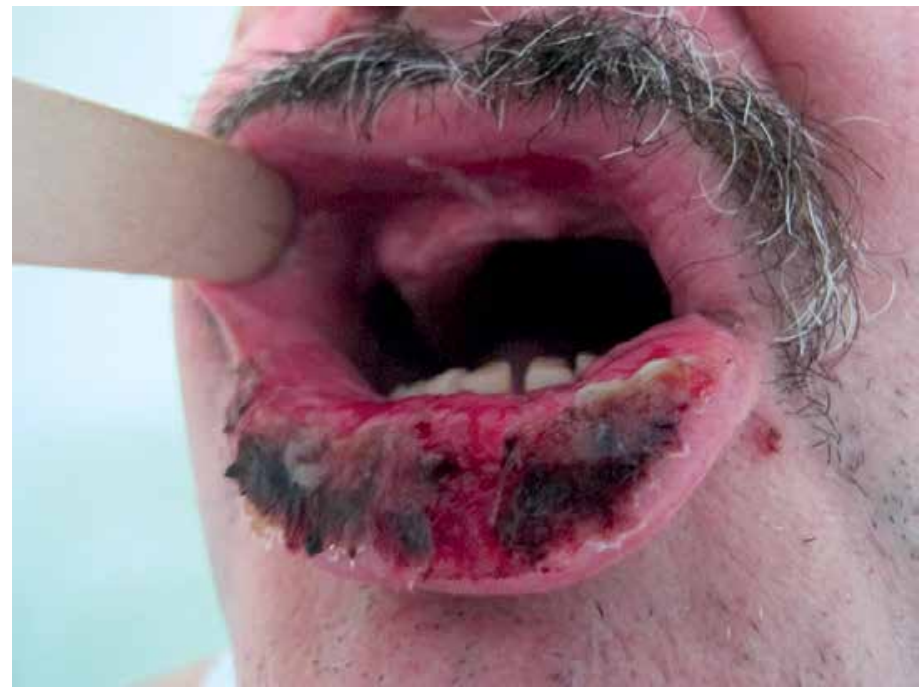

Figure 5. Mucous membrane pemphigoid

Rycina 5. Pemfigoid błon śluzowych

The incidence of EBA in Europe is estimated at 0.2 cases/1 million population/year [31].

The disease presents clinically as large tense bullae which are often located in areas exposed to mechanical injury: elbows, knees or dorsal hands. A characteristic feature during the process of skin lesion healing is the development of milia. The oral mucosa is rarely affected by bullae. The predominant lesions are erosions which may also involve the oesophagus [31].

\section{LINEAR IGA BULLOUS DERMATOSIS (LABD)}

Similarly to EBA, linear IgA bullous dermatosis is a rare chronic autoimmune disease. The incidence of LABD is estimated at $0.2-0.5$ cases $/ 1$ million population/year. The disease most frequently develops in patients over the age of 60 , although any age group may be affected $[32,33]$.

Itchy erythematous lesions accompanied by tense bullae are usually located on the face and scalp and in the genital area. Mucous membrane involvement, primarily by erosive lesions, is noted in $80 \%$ of cases [32-34].

A paediatric variant of the disease has also been identified, referred to as chronic bullous dermatosis of childhood (CBDC), in which mucous membranes are affected in up to $91 \%$ of all cases [34]. Mucosal lesions are often the sole manifestation of the disease. They are usually located on the mucous membranes of the oral cavity, genital areas and in the eyes. Linear IgA bullous dermatosis involving the mucosa of the oesophagus, larynx, trachea, nasal cavity and urethra has also been reported [35]. Skin lesions in adults affect mainly the trunk and extremities. Unlike in the predylekcji do płci. Zwykle dotyczy pacjentów między 40. a 60. rokiem życia. Częstość występowania w Europie szacuje się na 0,2 na milion rocznie [31].

W obrazie klinicznym występują duże, dobrze napięte pęcherze, często zlokalizowane $\mathrm{w}$ miejscach narażonych na uszkodzenia mechaniczne, takie jak łokcie, kolana i grzbiety rąk. Podczas gojenia się zmian na skórze charakterystycznie pojawiają się prosaki. Na błonach śluzowych jamy ustnej pęcherze stwierdza się rzadko. Przeważają nadżerki, które mogą obejmować także przełyk [31].

\section{LINIJNA IGA DERMATOZA PĘCHERZOWA (LINEAR IGA BULLOUS DERMATOSIS - LABD)}

Linijna IgA dermatoza pęcherzowa jest podobnie jak EBA rzadką, przewlekłą chorobą autoimmunologiczną. Częstość występowania szacuje się na 0,2-0,5 na milion rocznie. Najczęściej dotyczy osób po 60. roku życia, ale może pojawić się w każdej grupie wiekowej [32, 33].

Swędzące zmiany rumieniowe $\mathrm{z}$ dobrze napiętymi pęcherzami występują zwykle na twarzy, skórze owłosionej głowy oraz narządach płciowych. W 80\% przypadków zajęte są błony śluzowe, na których stwierdza się głównie zmiany nadżerkowe [32-34].

Wyodrębniono dziecięcy wariant choroby (chronic bullous dermatosis of childhood - CBDC), w którym błony śluzowe są zajęte nawet w 91\% przypadków [34]. Często śluzówki są jedyną lokalizacją choroby. Zwykle zmiany pojawiają się na błonach śluzowych jamy ustnej, w okolicach genitalnych oraz w obrębie narządu wzroku. Opisano także LABD z zajęciem błony śluzowej przełyku, krtani, tchawicy, jamy nosowej i cewki moczowej [35]. U dorosłych zmiany skórne obecne są 
paediatric variant, abnormalities in the genital areas are rarely seen [36]. Chronic bullous dermatosis of childhood is associated with bacterial superinfections by Staphylococcus aureus within the skin lesions more often than the adult form of the disease [37]. As a rule, the paediatric variant has a milder course, with spontaneous remissions noted usually 2 years after disease onset [36].

\section{CHRONIC ULCERATIVE STOMATITIS (CUS)}

Chronic ulcerative stomatitis is a rare disease of the oral mucosa. It usually develops in women between 30 and 60 years of age [38]. The aetiopathogenesis of CUS has not been fully clarified yet, however the disease is most likely autoimmune in nature. IgG-class squamous epithelium-specific antinuclear antibodies (SES-ANA) are detected in the serum of patients, often in very high titres [38-41]. SES-ANA are directed against nuclear antigens of cells in the basal layer of stratified squamous epithelium. The CUS antigen is a protein with a molecular weight of 70-72 kD, called CUSP (chronic ulcerative stomatitis protein). It is the cutaneous isoform of the p53 protein showing homology with the p53, p73 and KET antioncogenes. CUSP is the main KET protein transcript in keratinocytes [42].

The clinical features are not very distinctive. Mucosal lesions include erosions or ulcers located on the tongue, less commonly on the cheeks and gums, and very rarely on the hard palate and rubor labiorum (Fig. 6) [33, 34]. Mucosal lesions can be accompanied by lichen-like lesions on the skin. Generally, the subjective symptoms accompanying skin eruptions are very pronounced. Some authors zazwyczaj na tułowiu i kończynach, rzadko obserwuje się, w przeciwieństwie do wariantu dziecięcego, zmiany w okolicach genitalnych [36]. W dziecięcej postaci LABD częściej niż u dorosłych stwierdza się nadkażenia bakteryjne Staphylococcus aureus w obrębie zmian skórnych [37]. Postać dziecięca przebiega z reguły łagodniej, zwykle obserwuje się samoistne remisje po 2 latach trwania choroby [36].

\section{PRZEWLEKŁE WRZODZIEJACCE ZAPALENIE JAMY USTNEJ (CHRONIC ULCERATIVE STOMATITIS - CUS)}

Przewlekłe wrzodziejące zapalenie jamy ustnej jest rzadką chorobą błony śluzowej jamy ustnej, która najczęściej dotyczy kobiet między 30. a 60. rokiem życia [38]. Etiopatogeneza CUS nie została w pełni poznana. Najbardziej prawdopodobne wydaje się tło autoimmunologiczne. W surowicy chorych wykrywa się przeciwciała klasy IgG SES-ANA (squamous epitheliumspecific antinuclear antibodies), często w bardzo wysokich mianach [38-41]. Są to przeciwciała skierowane przeciwko antygenom jądrowym komórek warstwy podstawnej nabłonka wielowarstwowego płaskiego. Antygen CUS jest białkiem o masie cząsteczkowej 70-72 kD o nazwie CUSP (chronic ulcerative stomatitis protein). Jest to skórna izoforma białka p53, która wykazuje homologię z antyonkogenem p53, p73 oraz KET. CUSP jest głównym transkryptem białka KET w keratynocytach [42].

Obraz kliniczny jest mało charakterystyczny. Zmiany na błonach śluzowych to nadżerki lub owrzodzenia zlokalizowane na języku, nieco rzadziej na policzkach i dziąsłach, bardzo rzadko na podniebieniu twardym i czerwieni wargowej (ryc. 6) $[33,34]$. Mogą im towarzyszyć zmiany liszajopodobne

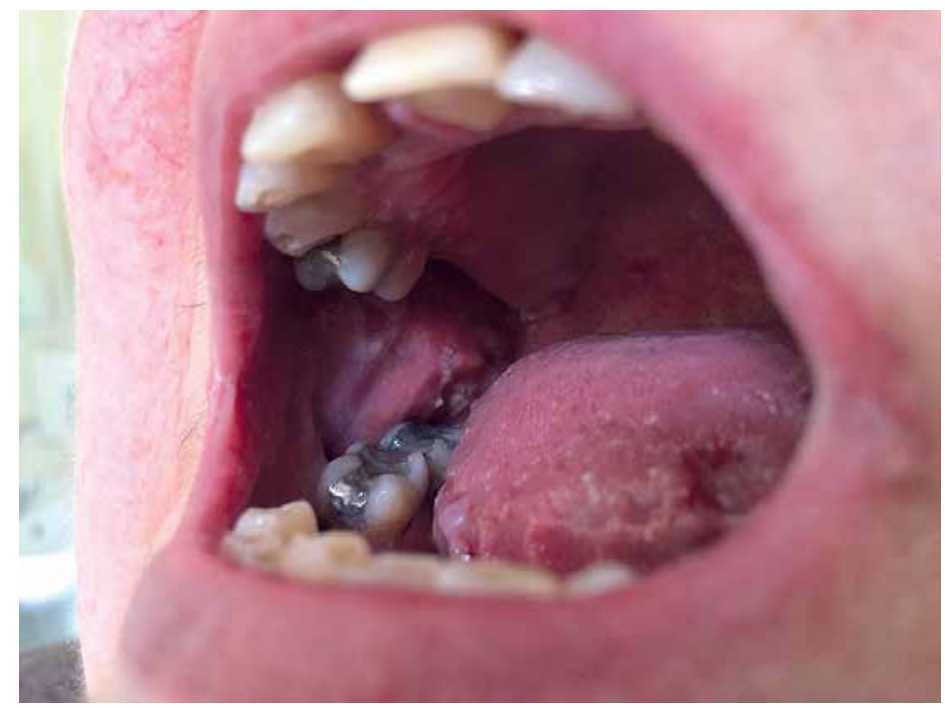

Figure 6. Chronic ulcerative stomatitis

Rycina 6. Przewlekłe wrzodziejq̨ce zapalenie jamy ustnej 
claim that CUS is a variant of LP rather than a separate nosological entity.

\section{CONCLUSIONS}

Skin lesions involving the oral mucosa pose significant diagnostic and therapeutic difficulties. All the nosological entities described above share similar clinical features, which makes it practically impossible to make a diagnosis without conducting specialist examinations.

\section{CONFLICT OF INTEREST}

The authors declare no conflict of interest.

\section{References}

\section{Piśmiennictwo}

1. Muramatsu K., Nishie W., Natsuga K., Fujita Y., Iwata H., Yamada T.: Two cases of erosive oral lichen planus with autoantibodies to desmoglein 3. J Dermatol 2016, 43, 1350-1353.

2. Trąbska M., Noberek-Wojciechowicz M.: Liszaj Wilsona błony śluzowej. Nowe spojrzenie na etiologię i leczenie. Czas Stomat 1998, 51, 643-649.

3. Gupta S., Jawanda MK.: Oral lichen planus: an update on etiology, pathogenesis, Clinical presentation, diagnosis and management. Indian J Dermatol 2015, 60, 222-229.

4. Scully C., Carrozzo M.: Oral mucosal disease: lichen planus. Br J Oral Maxillofac Surg 2008, 46, 15-21.

5. Scully C.: Choroby jamy ustnej. Diagnostyka i leczenie. Górska R (red.). Elsevier Urban \& Partner, Wrocław, 2004, 359-363.

6. Eisen D., Carrozzo M., Bagan Sebastian J.V., Thongprasom K.: Number V Oral lichen planus: clinical features and management. Oral Dis 2005, 11, 338-349.

7. Mollaoglu N.: Oral lichen planus: a review. Br J Oral Maxillofac Surg 2000, 38, 370-371.

8. Caroline S., Martins M., Luciana O., Meurer L., Squarize C., Manoela D., et al.: Epigenetic modifications and accumulation of DNA double-strand breaks in oral lichen planus lesions presenting poor response to therapy. Medicine (Baltimore) 2015, 94, e997.

9. Knychalska-Karwan Z.: Zmiany błony śluzowej jamy ustnej w schorzeniach o dużym prawdopodobieństwie etiologii immunologicznej. [W:] Fizjologia i patologia błony śluzowej jamy ustnej. J. Sławińska-Iwańczuk (red.). Czelej, Lublin 2002, 77-86.

10. Gümrü B.: A retrospective study of 370 patients with oral lichen planus in Turkey. Med Oral Patol Oral Cir Bucal 2013, 18, 427-432.

11. Kasperkiewicz M., Zillikens D., Schmidt E.: Pemphigoid diseases: pathogenesis, diagnosis, and treatment. Autoimmunity 2012, 45, 55-70.

12. Tamada Y., Yokochi K., Nitta Y., Ikeya T., Hara K., Owaribe K.: Lichen planus pemphigoides: identification of 180 kD hemidesmosome antigen. J Am Acad Dermatol 1995, 32, 883-887.

13. Shin-Ya H., Chin-Che Hsu R., Hsin-Su Y., Gwo-Shing C.: Lichen planus pemphigoides - a case report. Dermatol Sinica 2001, 19, 210-216.

14. Davis A.L., Bhogal B.S., Whitehead P.F., Frith P., Murdoch M.E., Leigh I.M., et al.: Lichen planus pemphigoides: its relationship to bullous pemphigoid. Br J Dermatol 1991, 125, 263-271.

15. Hsu S., Ghohestani R.F., Uitto J.: Lichen planus pemphigoides with IgG autoantibodies to the $180 \mathrm{kD}$ bullous pemphigoid antigen (type XVII collagen). J Am Acad Dermatol 2000, 42, 136-141.

16. Arnemann J., Spurr N.K., Buxton R.S.: The human gene (DSG3) coding for the pemphigus vulgaris antigen is, like the genes coding for the other two known desmogleins, assigned to chromosome 18. Hum Genet 1992, 89, 347-350.

17. Sitaru C., Mihai S., Zillikens D.: The relevance of the IgG subclass of autoantibodies for blister induction in autoimmune bullous skin diseases. Arch Dermatol Res 2007, 299, 1-8.

18. Ruocco V., Pelusa O., Pisani M.: Pemphigus vulgaris in only one of two monozygotic twins. J Am Acad Dermatol 1985, 12, 587-589.

19. Lenz P., Amagai M., Volc-Platzer B., Stingl G., Kirnbauer R.: Desmoglein 3-ELISA: a pemphigus vulgaris-specific diagnostic tool. Arch Dermatol 1999, 135, 143-148.

20. Mobini N., Padilla T., Ahmed A.R.: Long-term remission in selected patients with pemphigus vulgaris treated with cyclosporin. J Am Acad Dermatol 1997, 36, 264-266.

21. Sirois D., Leigh J.E., Sollecito T.P.: Oral pemphigus vulgaris preceding cutaneous lesions: recognition and diagnosis. J Am Dent Assoc 2000, 131, 1156-1160.

22. McCarty M., Fivenson D.: Two decades of using the combination of tetracycline derivatives and niacinamide as steroid-sparing agents in the management of pemphigus: defining a niche for these low toxicity agents. J Am Acad Dermatol 2014, 71, $475-479$. 
23. Kelly S., Schifter M., Fulcher D.A., Lin M.W.: Paraneoplastic pemphigus: two cases of intra-abdominal malignancy presenting solely as treatment refractory oral ulceration. J Dermatol 2015, 42, 300-304.

24. Anhalt G.J., Kim S.C., Stanley J.R., Korman N.J., Jabs D.A., Kory M., et al.: Paraneoplastic pemphigus. An autoimmune mucocutaneous disease associated with neoplasia. N Engl J Med 1990, 323, 1729-1735.

25. Hong-Hui X., Werth V., Parisi E., Sollecito T.: Mucous membrane pemphigoid. Dent Clin North Am 2013, 57, 611-630.

26. Freitas V.A., Goncales H.M., Giumardaes R.E., Franco L.P., Giumardaes F.F., Martins M.F.: Cicatricial pemphigoid in the upper aerodigestive tract: report of two cases. Rev Bras Otorinolaringol 2008, 74, 941-944.

27. Kwaśniewicz D., Białynicki-Birula R., Zalesska-Kręcicka M., Baran E., Morawska-Kochman M.: Pemfigoid bliznowaciejący - opis przypadku. Otorynolaryngologia 2011, 10, 134-137.

28. Higgins G., Allan R., Hall R., Field E., Kaye S.: Development of ocular disease in patients with mucous membrane pemphigoid involving the oral mucosa. Br J Ophthalmol 2006, 90, 964-967.

29. Foster C., Wilson L., Ekins M.: Immunosuppressive therapy for progressive ocular cicatricial pemphigoid. Ophthalmology $1982,89,340-353$.

30. Wójcicka-Rubin A., Kurnatowska A., Żebrowska A., Peterson-Jęckowska R.: Pemfigoid błon śluzowych - opis przypadku oraz uwagi diagnostyczno-terapeutyczne dla stomatologów. Dent Med Probl 2005, 42, 683-687.

31. Deen K., Wu J.: Porphyria cutanea tarda masquerading as epidermolysis bullosa acquisita: a report of two cases. Case Rep Dermatol 2015, 7, 129-135.

32. Lin M.S., Fu C.L., Olague-Marchan M.: Autoimmune responses in patients with linear IgA bullous dermatosis: both autoantibodies and T lymphocytes recognize the NC16A domain of the BP180 molecule. Clin Immunol 2002, 102, 310-319.

33. Egan C.A., Martineau M.R., Taylor T.B., Meyer L.J., Petersen M.J., Zone J.J.: IgA antibodies recognizing LABD97 are predominantly IgA1 subclass. Acta Derm Venereol 1999, 79, 343-346.

34. Dańczak-Pazdrowska A., Pazdrowski J., Bowszyc-Dmochowska M., Dmochowski M.: Zmiany w krtani w pęcherzycy zwykłej z dominacją zmian na błonach śluzowych. Otolaryngol Pol 2007, 61, 509-512.

35. Sokołowska-Wojdyło M., Sztaba-Kania M., Sobjanek M., Barańska-Rybak W., Dmochowski M.: Heterogeneity of clinical features of linear IgA bullous dermatosis (LABD) in the materials of the Laboratory of Immunodermatology and Serology in the Dermatology Department Medical University of Gdansk. Post Dermatol Alergol 2007, 24, 82-88.

36. Ishiko A., Shimizu H., Masunaga T., Hashimoto T., Dmochowski M., Wojnarowska F., et al.: 97-kDa linear IgA bullous dermatosis (LAD) antigen localizes to the lamina lucida of the epidermal basement membrane. J Invest Dermatol 1996, 106, 739-743.

37. Guide S.V., Marinokovich M.P.: Linear IgA bullous dermatosis. Clin Dermatol 2001, 19, 719-727.

38. Solomon L.W., Aguirre A., Neiders M., Costales-Spindler A., Jividen G. Jr., Zwick M.G., et al.: Chronic ulcerative stomatitis: clinical, histopathologic and immunopathologic findings. Oral Surg Oral Med Oral Pathol 2003, 96, 718-726.

39. Lewis J.E., Beutner E.H, Rostami R., Chorzelski T.P.: Chronic ulcerative stomatitis with stratified epitelium - specific antinuclear antibodies. Int J Dermatol 1996, 35, 272-275.

40. Peterson-Jęckowska R., Dudko A., Kurnatowska A.J.: Trudności diagnostyczne i terapeutyczne w przewlekłych zmianach nadżerkowych w jamie ustnej - opis przypadku. Dent Med Probl 2004, 41, 783-788.

41. Solomon L.: Chronic ulcerative stomatitis. Oral Dis 2008, 14, 383-389.

42. Lee L.A., Walsh P., Prater C.A., Su L.J., Marchbank A., Egbert T.B., et al.: Characterization of an autoantigen associated with chronic ulcerative stomatitis: the CUSP autoantigen is a member of the p53 family. J Invest Dermatol 1999, 113, 146-151.

Received: 12.07 .2016

Accepted: 30.09 .2017

Otrzymano: 12.07.2016 r.

Zaakceptowano: $30.09 .2017 \mathrm{r}$.

How to cite this article

Ociepa K., Żebrowska A.: Diseases presenting with vesicular and erosive lesions of oral mucous membranes. Dermatol Rev/ Przegl Dermatol 2017, 104, 509-518, DOI: https://doi.org/10.5114/dr.2017.71216. 